https://journal.univetbantara.ac.id/index.php/jbfe

\title{
PENGARUH PENDIDIKAN KEWIRAUSAHAAN DAN LINGKUNGAN KELUARGA TERHADAP MINAT BERWIRAUSAHA MAHASISWA FAKULTAS EKONOMI UNIVERSITAS VETERAN BANGUN NUSANTARA SUKOHARJO
}

\author{
Guntur Saputra \\ Yoppi Syahrial \\ Andiyas Miawan \\ Fakultas Ekonomi, Universitas Veteran Bangun Nusantara Sukoharjo \\ Gunturcb97@gmail.com
}

\begin{abstract}
ABSTRAK
Tujuan penelitian ini adalah untuk menguji dan mengetahui pengaruh Pendidikan Kewirausahaan dan Lingkungan Keluarga terhadap Minat Berwirausaha Mahasiswa Fakultas Ekonomi Universitas Veteran Bangun Nusantara Sukoharjo. Sampel dalam penelitian ini yaitu 76 Mahasiswa Fakultas Ekonomi Universitas Veteran Bangun Nusantara Sukoharjo. Pengujian hipotesis dalam penelitian ini menggunakan analisis regresi linear berganda. Hasil penelitian ini menunjukkan bahwa pendidikan kewirausahaan berpengaruh positif terhadap minat berwirausaha, selain itu lingkungan keluarga tidak berpengaruh terhadap minat berwirausaha serta pendidikan kewirausahaan dan lingkungan keluarga berpengaruh secara simultan terhadap minat berwirausaha.
\end{abstract}

Kata kunci : Pendidikan Kewirausahaan, Lingkungan Keluarga, Minat Berwirausaha 


\section{PENDAHULUAN}

Pengangguran merupakan suatu masalah yang tidak ada habisnya di Indonesia. Banyaknya angkatan kerja yang ingin memasuki dunia kerja tidak sebanding dengan lapangan pekerjaan yang tersedia, sehingga membuat banyak orang tidak mendapat pekerjaan yang dampaknya bertambah pengangguran di Indonesia. Menurut data Badan Pusat Statistik (BPS) di Indonesia jumlah pengangguran dari agustus tahun 2018 sampai agustus tahun 2020 mengalami peningkatan. Pada tahun

2018 yaitu 7,07 juta orang naik menjadi 7,10 juta orang pada tahun 2019, sedangkan pada tahun 2020 meningkat menjadi 9,77 juta orang lebih banyak dibandingkan tahun sebelumnya (bps.go.id). Tingkat pengangguran terbuka (TPT) mengalami penurunan pada tahun 2019, pada agustus 2019 Tingkat pengangguran terbuka (TPT) turun menjadi 5,23\% dibandingkan tahun 2018 sebesar 5,30\%. Sedangkan tingkat pengangguran terbuka (TPT) pada agustus tahun 2020 sebesar $7,07 \%$ meningkat

1,84\% dibanding agustus 2019 (bps.go.id). Tingkat pengangguran terbuka (TPT) di Indonesia ini akan semakin meningkat apabila tidak di imbangi dengan disediakannya lapangan pekerjaan baru.

Terjadinya pengangguran disebabkan oleh sulitnya mendapat pekerjaan ditengah persaingan yang ketat (Adi jaya \& seminari, 2016). Badan Pusat Statistik (BPS) di Indonesia mencatat tingkat pengangguran terbuka (TPT) menurut pendidikan tertinggi pada bulan agustus tahun 2020 mengalami peningkatan dibandingkan tahun sebelumnya. Salah satunya yaitu lulusan universitas dengan jumlah 7,35\% pada agustus 2020 dibadingkan agustus 2019 yaitu 5,64\% (bps.go.id). Fenomena ini disebabkan oleh rendahnya minat serta motivasi seseorang untuk berwirausaha, di karnakan selama ini seseorang hanya berminat sebagai pencari kerja job seeker apabila kelak menyelesaikan sekolah atau kuliah mereka (lestari \& wijaya, 2012). Salah satu solusi yang ditempuh dalam mengatasi pengangguran di Indonesia dengan menciptakan wirausaha. Dengan berwirausaha, akan membantu pemerintah dalam menciptakan lapangan pekerjaan baru. Wirausaha juga berkontribusi pada perekonomian negara melalui pajak yang dihasilkan (Perkasa, Triansah, \& Iskandar, 2020).

Banyak masalah ekonomi menjadi penyebab seseorang beralih ke wirausaha atau membuka bisnis mereka sendiri. Pilihan sebagai seorang wirausaha tampak sebagai salah satu solusi yang tepat, dikarenakan seseorang tidak menggantungkan diri pada lapangan pekerjaan yang ada, tapi mulai berpikir bagaimana cara agar dapat menciptakan lapangan pekerjaan sendiri (Zulfikar \& Sobandi, 


\section{https://journal.univetbantara.ac.id/index.php/jbfe}

2020). Kewirausahaan yaitu semangat, sikap, perilaku, serta kemampuan seseorang dalam menangani usaha atau kegiatan yang mengarah pada upaya mencari, menciptakan, serta menerapkan cara kerja, teknologi dan produksi dengan meningkatkan efisiensi dalam rangka memberikan pelayanan yang lebih baik atau memperoleh keuntungan yang lebih besar (Latief, 2017). Kewirausahaan yaitu suatu sikap, 


\section{https://journal.univetbantara.ac.id/index.php/jbfe}

jiwa dan kemampuan untuk menciptakan sesuatu yang baru, bernilai serta berguna bagi diri dan orang lain (Perkasa, Triansah, \& Iskandar, 2020).

Dalam meningkatkan semangat seseorang untuk berwirausaha harus menumbuhkan minat berwirausaha dimulai dari sekarang. Minat merupakan seperangkat mental yang kuat tediri dari campuran antara perasaan, harapan, pendirian, kecenderungan yang mengarahkan individu kepada suatu pilihan tertentu (Yusuf \& Sutanti, 2020). Selain itu, minat merupakan kecedrungan yang agak menetap pada seseorang untuk merasa tertarik pada suatu bidang tertentu serta merasa senang berkecimpung dalam berbagai kegiatan yang berkaitan dengan bidang itu (Perkasa, Triansah, \& Iskandar, 2020). Adapun hal-hal yang mempengaruhi minat berwirausaha yaitu faktor internal dan faktor external. faktor internal merupakan minat seseorang yang berasal dari dalam diri sendiri yaitu perhatian, keingintahuan, motivasi dan kebutuhan. Sedangkan faktor external merupakan minat seseorang yang berasal dari luar diri yaitu dorongan dari orang tua, dorongan dari guru, tersedianya fasilitas, serta keadaan lingkungan seperti lingkungan keluarga, pendidikan dan pergaulan (Yusuf \& Sutanti, 2020).

Jadi minat berwirausaha dikalangan mahasiswa dapat dipengaruhi oleh beberapa faktor, diantaranya pendidikan kewirausahaan dan lingkungan keluarga (Yusuf \& Sutanti, 2020). Pendidikan kewirausahaan dapat membentuk pola pikir, sikap, dan perilaku pada peserta didik siswa/mahasiswa menjadi seorang wirausaha sehingga mengarahkan mereka untuk memilih berwirausaha sebagai pilihan karir (Lestari \& Wijaya, 2012). Serta pendidikan kewirausahaan juga mampu memberi wawasan pada peserta didik. Wawasan kewirausahaan merupakan mendidik para calon pengusaha untuk memiliki kemandirian, keberanian, serta ketrampilan dalam berwirausaha, sehingga pelaku dapat meminimalisir kegagalan dalam berwirausaha (Munawar, 2019). Oleh karena itu pendidikan kewirausahaan dapat mendorong dan menumbuhkan minat berwirausaha. Penelitian yang dilakukan oleh Tangkeallo \& Tangdialla (2021) serta Cahyani, Wiyono, \& Benty (2020) Pendidikan kewirausahaan berpengaruh positif dan signifikan terhadap minat berwirausaha.

Berkaitan dengan lingkungan keluarga, merupakan media pertama dan utama yang mempengaruhi perilaku dalam perkembangan anak, orang tua berperan sebagai pengarah untuk masa depan (Hutagalung, Dalimunthe, Pambudi, Hutagalung, \& Muda, 2017). Lingkungan keluarga yaitu sekelompok masyarakat terkecil yang terdiri dari ayah, ibu, anak serta anggota keluarga lainnya (Oktarina, Agung, \& Aswad, 2019). Lingkungan keluarga terutama orang tua berperan penting dalam mempengaruhi minat terhadap pekerjaan bagi anak di masa yang akan datang, termasuk dalam hal berwirausaha (Arisanti \& Nafitasari, 2020). Lingkungan keluarga merupakan pendidikan pertama bagi anak dan bertanggung jawab untuk mengembangkan segala bakat, minat 
Journal of Business Finance and Economic (JBFE)

Volume 2, Nomor 2, Desember 2021

E-ISSN: 2746-6914

https://journal.univetbantara.ac.id/index.php/jbfe

serta potensi yang dimiliki anak sejak dini (Khotimah, 2020). Maka dari itu lingkungan keluarga dapat mempengaruhi minat 


\section{https://journal.univetbantara.ac.id/index.php/jbfe}

seseorang untuk menentukan karirnya dimasa yang akan datang, termasuk dalam hal berwirausaha. Dari penelitian yang dilakukan Arisanti \& Nafitasari (2020) serta Aini \& Oktafani (2020) bahwa lingkungan keluarga berpengaruh positif terhadap minat berwirausaha. Selain itu pendidikan kewirausahaan dan lingkungan keluarga diduga berpengaruh secara simultan terhadap minat berwirausaha. Menurut penelitian Wahyuningsih (2020) serta Khoeriyah, Muamar \& Bakhri (2019) menunjukkan pengaruh bersama-sama antara pendidikan kewirausahaan dan lingkungan keluarga terhadap minat berwirausaha mahasiswa. Berdasarkan latar belakang dan fenomena di atas peneliti tertarik untuk melakukan penelitian dengan judul "Pengaruh Pendidikan Kewirausahaan dan Lingkungan Keluarga Terhadap Minat Berwirausaha

Mahasiswa". Karena dengan berwirusaha diharapkan mampu merubah pola pikir budaya mencari kerja menjadi budaya menciptakan kerja khususnya bagi lulusan lulusan baru.

\section{KAJIAN TEORITIS}

Definisi Pendidikan Kewirausahaan

Pendidikan Kewirausahaan merupakan proses pembelajaran pembentukan untuk mengubah sikap, dan pola pikir peserta didik siswa/mahasiswa terhadap pilihan karir wirausaha (Lestari \& Wijaya, 2012). Pendidikan kewirausahaan adalah pendidikan dan pemahaman dasar yang memungkinkan peserta didik siswa/mahasiswa untuk mengembangkan, menggunakan kriativitas, inisiatif, tanggung jawab serta belajar mengambil resiko dan menghadapi resiko (Kurnia, Muhlisin,

\& Munawar, 2017). Entrepreneur dapat dikenalkan serta dilatih dengan beberapa cara yaitu dalam bidang pendidikan, dapat diajarkan melalui pelajaran kewirausahaan, pelatihan khusus mengenai entrepreneur, seminar entrepreneurship, dan peraktik langsung kegiatan kewirausahaan (Kurnia , Muhlisin, \& Munawar, 2017). Berdasarkan definisi-definisi diatas bisa di simpulkan bahwa pendidikan kewirausahaan merupakan pembentukan pola pikir dan sikap peserta didik untuk menuangkan gagasan atau ide melalui kriativitas, inisiatif serta belajar untuk mengambil resiko dan menghadapi resiko yang akan datang.

\section{Definisi Lingkungan Keluarga}

Lingkungan keluarga yaitu sekelompok masyarakat terkecil yang terdiri dari ayah, ibu, anak serta anggota keluarga lainnya (Oktarina, Agung, \& Aswad, 2019). Lingkungan keluarga adalah lingkungan pertama dan paling utama yang di kenal seseorang serta memberikan peranan penting dalam perkembangan tingkah laku seseorang (Omardi, Talkah, \& Daroini, 2020). Lingkungan keluarga adalah tempat pembelajaran pertama bagi anak-anak pada saat kecil (Aini 
Journal of Business Finance and Economic (JBFE)

Volume 2, Nomor 2, Desember 2021

https://journal.univetbantara.ac.id/index.php/jbfe

\& Oktafani,

2020). Lingkungan keluarga lingkungan untuk melatih serta mengasah karakter kewirausahaan dan juga dapat menjadi bekal pada anak untuk mulai mengarahkan minat di kemudian harinya (Anand 
\& Meftahudin, 2020). Berdasarkan definisi-definisi diatas bisa disimpulkan bahwa lingkungan keluarga merupakan masyarakat kecil yang membentuk kelompok, terdiri dari ayah, ibu dan anak yang mempunyai tugas dan kewajiban masing-masing, serta tempat pertama dimana anak memdapatkan pembelajaran pertamanya di masa kecil yang dapat mempengaruhi tumbuh kembangnya seorang anak di masa yang akan datang.

\section{Definisi Minat Berwirausaha}

Minat wirausaha merupakan suatu keadaan pikiran seseorang ingin menciptakan usaha sendiri dan memiliki niat untuk memulai usaha baru (Widianingrum, 2020). Minat wirausaha berasal dari dalam diri seseorang untuk menciptakan sebuah bidang usaha. Minat wirausaha merupakan kecendrungan hati dalam diri untuk tertarik menciptakan suatu usaha yang kemudian mengatur, menanggung resiko serta mengembangkan usaha yang diciptakannya tersebut. Minat wirausaha merupakan kemampuan untuk memberanikan diri dalam memenuhi kebutuhan hidup serta memecahkan permasalahan hidup, memajukan usaha atau menciptakan usaha baru dengan kekuatan yang ada pada diri sendiri (Novitasyari, Setiawati, \& Rahmawati, 2017). Minat berwirausaha yaitu keinginan, ketertarikan, serta kesediaan individu melalui ide yang memiliki untuk bekerja keras atau berkemauan keras untuk berusaha memenuhi kebutuhan hidupnya, tanpa merasa takut dengan resiko yang akan terjadi,dapat menerima tantangan, kepercayaan diri, kreatif, serta inovatif mempunyai kemampuan dan keterampilan untuk meraih kesuksesan (Ghurfiana, 2018). Dari definisi-definisi diatas bisa disimpulkan bahwa minat berwirausaha adalah keinginan atau pola pikir seseorang untuk memulai usaha baru dengan keberanian untuk mengambil resiko dan meminimalis resiko untuk memenuhi kebutuhan hidupnya.

\section{HIPOTESIS PENELITIAN}

Pendidikan kewirausahaan dapat membentuk pola pikir, sikap, dan perilaku pada peserta didik siswa/mahasiswa menjadi seorang wirausaha sejati sehingga mengarahkan mereka untuk memilih berwirausaha sebagai pilihan karir (Lestari \& Wijaya, 2012). Pendidikan kewirausahaan adalah pendidikan dan pemahaman dasar yang memungkinakan peserta didik siswa/mahasiswa untuk mengembangkan, menggunakan kriativitas, inisiatif, tanggung jawab serta belajar mengambil resiko dan menghadapi resiko (Kurnia, Muhlisin, \& Munawar, 2017). Dalam penelitian yang dilakukan oleh Tangkeallo \& Tangdialla (2021) serta Cahyani, Wiyono, \& Benty (2020) menunjukkan bahwa terdapat pengaruh positif signifikan pendidikan kewirausahaan terhadap minat berwirausaha. Dengan demikian hipotesis pertama yang di ajukan 
Journal of Business Finance and Economic (JBFE)

P-ISSN: 2746-6906

Volume 2, Nomor 2, Desember 2021

E-ISSN: 2746-6914

https://journal.univetbantara.ac.id/index.php/jbfe

dalam penelitian ini adalah.H1: Diduga Pendidikan Kewirausahaan berpengaruh positif terhadap Minat Berwirausaha mahasiswa. 
https://journal.univetbantara.ac.id/index.php/jbfe

Lingkungan keluarga yaitu sekelompok masyarakat terkecil yang terdiri dari ayah, ibu, anak serta anggota keluarga lainnya (Oktarina, Agung, \& Aswad, 2019). Lingkungan keluarga terutama orang tua berperan penting dalam mempengaruhi minat terhadap pekerjaan bagi anak di masa yang akan datang, termasuk dalam hal berwirausaha (Arisanti \& Nafitasari, 2020). Lingkungan keluarga lingkungan untuk melatih serta mengasah karakter kewirausahaan dan juga dapat menjadi bekal pada anak untuk mulai mengarahkan minat di kemudian harinya (Anand \& Meftahudin, 2020). Dari definisi-definisi diatas mengenai lingkungan keluarga, bahwa lingkungan keluarga dapat mempengaruhi minat seseorang untuk berwirausaha. Dalam penelitian yang dilakukan oleh Arisanti

\& Nafitasari (2020) serta Aini \& Oktafani (2020) terdapat pengaruh positif signifikan lingkungan keluarga terhadap minat berwirausaha. Selain itu menurut penelitian Wahyuningsih (2020) serta Khoeriyah, Muamar \& Bakhri (2019) menunjukkan pengaruh bersama-sama antara pendidikan kewirausahaan dan lingkungan keluarga terhadap minat berwirausaha mahasiswa.. Dengan demikian hipotesis kedua dan ketiga dalam penelitian ini adalah H2: Diduga Lingkungan Keluarga berpengaruh positif terhadap Minat Berwirausaha mahasiswa. H3: Diduga Pendidikan Kewirausahaan dan Lingkungan Keluarga berpengaruh secara bersama-sama terhadap Minat Berwirausaha Mahasiswa.

\section{METODE PENELITIAN}

* Metode penelitian

Metode yang digunakan dalam penelitian ini adalah menggunakan metode kuantitatif. Menurut (Sugiyono, 2011) metode kuantitatif yaitu metode penelitian yang berlandasan pada filsafat positivisme, digunakan untuk meneliti pada populasi atau sampel tertentu.

\section{* Populasi dan Sampling}

Populasi dalam penelitian ini adalah mahasiswa Fakultas Ekonomi Universitas Veteran Bangun Nusantara Sukoharjo angkatan 2018 yaitu 95 mahasiswa. Pengambilan sampel dalam penelitian ini menggunakan desain probability sampling dengan teknik stratified random sampling.

Penentuan jumlah sampel sebagai berikut (Ferdinand, 2014).

$$
\mathrm{n}=\frac{\mathrm{N}}{1+\mathrm{Nd}^{2}}
$$

$\mathrm{n}=95$ 
Journal of Business Finance and Economic (JBFE)

Volume 2, Nomor 2, Desember 2021

https://journal.univetbantara.ac.id/index.php/jbfe

$$
\begin{aligned}
& \quad 1+95(5 \%)^{2} \\
& =76 \text { sampel }
\end{aligned}
$$

Kemudian dilakukan penarikan jumlah sampel dengan menggunakan propbability sampling berupa stratified random sampling. 
Journal of Business Finance and Economic (JBFE)

Volume 2, Nomor 2, Desember 2021

https://journal.univetbantara.ac.id/index.php/jbfe
P-ISSN: 2746-6906

E-ISSN: 2746-6914

Jurusan SDM

$($ sumber daya manusia $)=41$ x $76=33$ sampel

Maka, dalam strata jurusan didapatkan sampel jurusan keuangan 28 sampel, jurusan pemasaran 15 sampel, jurusan SDM (sumber daya manusia) 33 sampel.

\section{TEKNIK PENGUMPULAN DATA}

Teknik pengumpulan data yang digunakan dalam penelitian ini adalah penyebaran angket dengan google formulir sebagai media penyebarannya. Penyebaran angket berfungsi untuk mengumpulkan data tertulis, dengan cara membagikan link google formulir secara online melalui media sosial. Angket dapat berupa pertanyaan terbuka ataupun tertutup. Dalam penelitian ini menggunakan angket tertutup, sehingga responden hanya memilih jawaban sesuai skala yang telah tersedia dari pertanyaan yang ada. Sekala liker yang digunakan dalam penelitian ini, Skala likert yaitu skala yang digunakan untuk mengukur sikap, pendapat, serta persepsi seseorang atau kelompok orang tentang fenomena sosial (Sugiyono, 2011).

\section{DEFINISI OPERASIONAL DAN PENGUKURAN}

Pendidikan Kewirausahaan

Pendidikan kewirausahaan adalah pendidikan dan pemahaman dasar yang memungkinkan peserta didik siswa/mahasiswa untuk mengembangkan, menggunakan kriativitas, inisiatif, tanggung jawab serta belajar mengambil resiko dan menghadapi resiko (Kurnia , Muhlisin, \& Munawar, 2017). Berdasarkan definisi diatas bisa di simpulkan bahwa pendidikan kewirausahaan merupakan pembentukan pola pikir dan sikap peserta didik untuk menuangkan gagasan atau ide melalui kriativitas, inisiatif serta belajar untuk mengambil resiko dan menghadapi resiko yang akan 
Journal of Business Finance and Economic (JBFE)

P-ISSN: 2746-6906

Volume 2, Nomor 2, Desember 2021

E-ISSN: 2746-6914

https://journal.univetbantara.ac.id/index.php/jbfe

datang. Pengukuran 


\section{https://journal.univetbantara.ac.id/index.php/jbfe}

pendidikan kewirausahan dalam penelitian ini menggunakan 5 item pernyataan yang diadaptasi dari Herawati (2018).

\section{Lingkungan Keluarga}

Lingkungan keluarga, lingkungan untuk melatih serta mengasah karakter kewirausahaan dan juga dapat menjadi bekal pada anak untuk mulai mengarahkan minat di kemudian harinya (Anand \& Meftahudin, 2020). Pengukuran lingkungan keluarga dalam penelitian ini menggunakan 5 item pernyataan yang diadaptasi dari Herawati (2018).

\section{Minat Berwirausaha}

Minat wirausaha merupakan kemampuan untuk memberanikan diri dalam memenuhi kebutuhan hidup serta memecahkan permasalahan hidup, memajukan usaha atau menciptakan usaha baru dengan kekuatan yang ada pada diri sendiri (Novitasyari, Setiawati, \& Rahmawati, 2017). Definisi diatas bisa disimpulkan bahwa minat berwirausaha adalah keinginan atau pola pikir seseorang untuk memulai usaha baru dengan keberanian untuk mengambil resiko dan meminimalis resiko untuk memenuhi kebutuhan hidupnya. Pengukuran minat berwirausaha dalam penelitian ini menggunakan 5 item pernyataan yang diadaptasi dari Herawati (2018).

\section{HASIL UJI PEMBAHASAN}

Karakteristik Responden

Tabel 4.2

Distribusi Karakteristik Responden

\begin{tabular}{|c|c|c|}
\hline Karakteristik & Frekuensi & Persentase (\%) \\
\hline \multicolumn{3}{|c|}{ Semester } \\
\hline Semester 6 & 76 & $100 \%$ \\
\hline \multicolumn{3}{|c|}{ Jurusan } \\
\hline Keuangan & 28 & $36,8 \%$ \\
\hline SDM & 33 & $43,4 \%$ \\
\hline Pemasaran & 15 & $19,7 \%$ \\
\hline \multicolumn{3}{|c|}{ Jenis kelamin } \\
\hline Laki-laki & 15 & $19,7 \%$ \\
\hline Perempuan & 61 & $80,3 \%$ \\
\hline \multicolumn{2}{|c|}{ Pekerjaan orang tua } \\
\hline Wiraswasta & 37 & $48,7 \%$ \\
\hline Petani & 14 & $18,4 \%$ \\
\hline
\end{tabular}


Journal of Business Finance and Economic (JBFE)

P-ISSN: 2746-6906

Volume 2, Nomor 2, Desember 2021

E-ISSN: 2746-6914

https://journal.univetbantara.ac.id/index.php/jbfe

\begin{tabular}{|l|l|l|}
\hline PNS & 6 & $7,9 \%$ \\
\hline
\end{tabular}


Journal of Business Finance and Economic (JBFE)

https://journal.univetbantara.ac.id/index.php/jbfe

\begin{tabular}{|c|c|c|}
\hline IRT & 1 & $1,3 \%$ \\
\hline Buruh & 8 & $10.5 \%$ \\
\hline Pedagang & 5 & $6,6 \%$ \\
\hline Sopir & 2 & $2,6 \%$ \\
\hline Swasta & 3 & $3,9 \%$ \\
\hline
\end{tabular}

Sumber : Data Primer yang diolah, 2021

* Hasil Uji Instrumen Penelitian

Tabel 4.6

\section{KMO and Bartlett's Test}

\begin{tabular}{|c|c|}
\hline $\begin{array}{l}\text { Kaiser-Meyer-Olkin Measure of Sampling } \\
\text { Adequacy. }\end{array}$ & .774 \\
\hline Approx. Chi-Square & 320.303 \\
\hline Bartlett's Test of $\mathrm{df}$ & 78 \\
\hline Sphericity & .000 \\
\hline
\end{tabular}

tabel 4.6 uji validitas Yang telah dilakukan menunjukkan hasil nilai KMO Measure of Sampling Adequacy (MSA) dalam penelitian ini sebesar 0,774. Karena nilai KMO MSA diatas 0,50 serta nilai Berlett's test dengan Chi-square $=320,303$ dan signifikan pada 0,000 dapat disimpulkan

bahwa uji analisis faktor dapat dilanjutkan.

Tabel 4.8

Hasil Uji Reliabilitas

\begin{tabular}{|l|c|}
\hline \multicolumn{1}{|c|}{ Variable } & Cronbach'sAlpha \\
\hline Pendidikan kewirausahaan & 0,644 \\
\hline Lingkungan keluarga & 0,847 \\
\hline Minat berwirausaha & 0,676 \\
\hline \multicolumn{2}{|c|}{ Sumber: Data Primer yang diolah, 2021 } \\
\hline
\end{tabular}

dari tabel 4.8 dapat disimpulkan bahwa secara umum semua variable penelitian dinyatakan reliable karena mempunyai nilai Cronbach's Al pha $>0,60$.

* Hasil Uji Hipotesis 
Journal of Business Finance and Economic (JBFE)

P-ISSN: 2746-6906

Volume 2, Nomor 2, Desember 2021

E-ISSN: 2746-6914

https://journal.univetbantara.ac.id/index.php/jbfe

Untuk menguji hipotesis dalam penelitian ini menggunakan metode analisis regresi linear berganda. Berikut ini tapilan model regresi dengan menggunakan bantuan SPSS 20: 


\section{https://journal.univetbantara.ac.id/index.php/jbfe}

Tabel 4.9

\section{Hasil Analisis Regresi Linear Berganda}

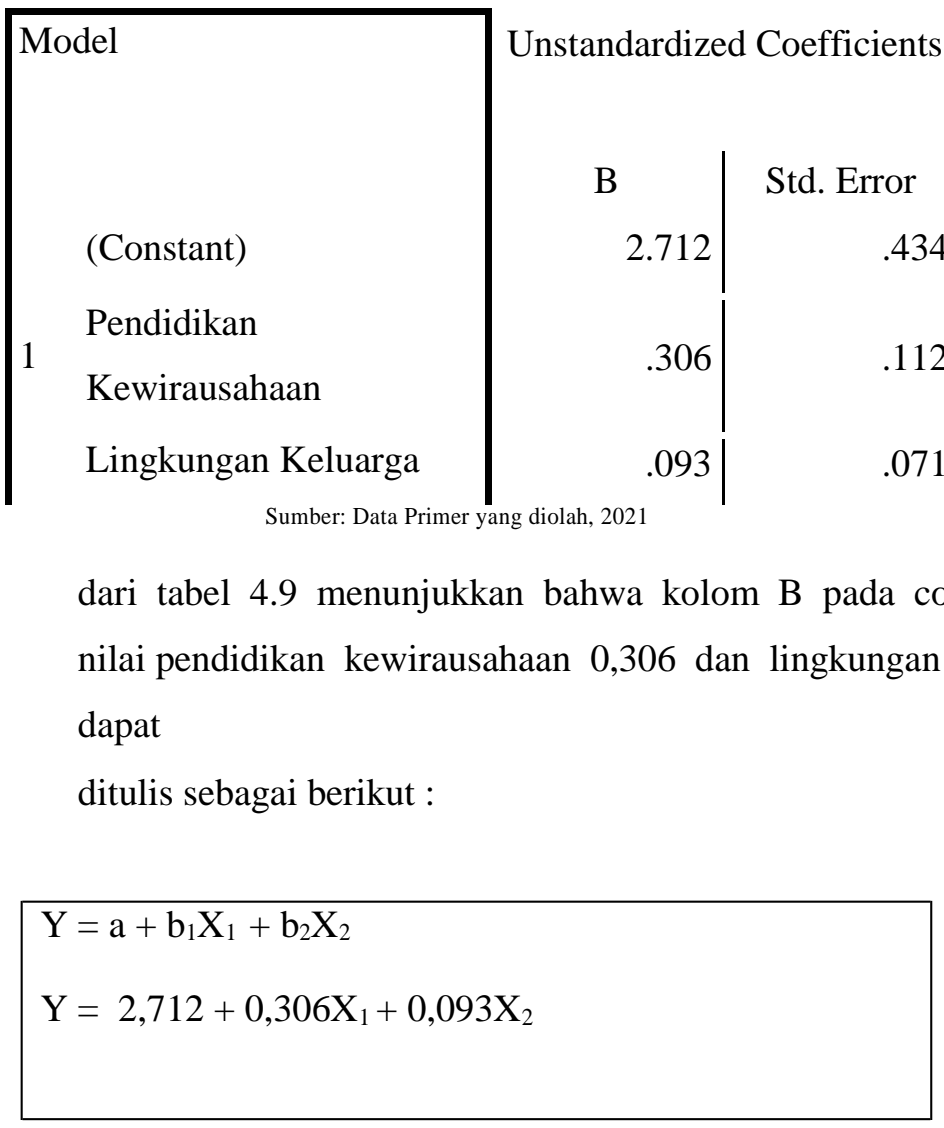

Tabel 4.10

Hasil Koefisien Determinasi

\begin{tabular}{|c|c|c|c|c|}
\hline Model & $\mathrm{R}$ & R Square & $\begin{array}{l}\text { Adjusted R } \\
\text { Square }\end{array}$ & $\begin{array}{l}\text { Std. Error of } \\
\text { the Estimate }\end{array}$ \\
\hline 1 & $.402^{\mathrm{a}}$ & .161 & .138 & .446 \\
\hline
\end{tabular}

dari tabel 4.10 menunjukkan bahwa $R$ Square adalah 0,161 yang artinya bahwa variable pendidikan kewirausahaan dan lingkungan keluarga berpengaruh terhadap minat berwirausaha sebesar 0,161 atau 16,1\% sedangkan sisanya dipengaruhi oleh variable lain yang tidak dibahas dalam penelitian ini yaitu 83,9\%. Variabel X1 dan X2 dalam penelitian ini berpengaruh secara simultan terhadap variabel $\mathrm{Y}$ dengan nilai $\mathrm{F}$ hitung > F tabel yaitu 6,919> 3,12 . 
Hasil Uji F (X1,X2 Terhadap Y)

\begin{tabular}{|c|c|}
\hline F hitung & Sig. \\
\hline 6,919 & $0,002^{\mathrm{b}}$ \\
\hline Sumber: Data Primer yang diolat, 2021 & \\
\hline
\end{tabular}

Tabel 4.12

Hasil Uji T Tahun 2021

\begin{tabular}{|c|c|}
\hline $\mathbf{t}$ & Sig. \\
\hline 2,731 & 0,008 \\
\hline 1,304 & 0,197 \\
\hline Sumber: Data Primer yang diolah, 2021 & \\
\hline
\end{tabular}

Dari pengujian diatas menunjukkan hasil bahwa variabel X1 berpengaruh positif secara parsial terhadap variabel $\mathrm{Y}$. artinya pendidikan kewirausahaan berpengaruh positif secara parsial terhadap minat berwirausaha Mahasiswa Fakultas Ekonomi Universitas Veteran Bangun Nusantara Sukoharjo, dengan nilai $\mathrm{T}_{\text {hitung }}>\mathrm{T}_{\text {tabel }}$ yaitu 2,731>1,666. Kemudian pada variabel X2 menunjukkan tidak ada pengaruh secara parsial terhadap variabel Y. Artinya lingkungan keluarga tidak berpengaruh secara parsial terhadap minat berwirausaha Mahasiswa Fakultas Ekonomi Universitas Veteran Bangun Nusantara Sukoharjo, dengan nilai $\mathrm{T}_{\text {hitung }}<\mathrm{T}_{\text {tabel }}$ yaitu 1,304 $<1,666$.

* Pembahasan

a. Pengaruh pendidikan kewirausahaan terhadap minat berwirausaha

Hasil penelitian menunjukkan bahwa pendidikan kewirausahaan berpengaruh positif terhadap minat berwirausaha Mahasiswa Fakultas Ekonomi Universitas Veteran Bangun Nusantara Sukoharjo. Hal ini ditunjukkan dari hasil uji parsial atau uji T terdapat pengaruh secara parsial pendidikan kewirausahaan terhadap minat berwirausaha, dengan nilai $\mathrm{T}_{\text {hitung }}>\mathrm{T}_{\text {tabel }}$ yaitu $2,731>1,666$. Bisa disimpulkan semakin tinggi pendidikan kewirausahaan yang di dapat Mahasiswa FE UVBN maka minat berwirausaha akan semakin meningkat. Hasil penelitian ini mendukung penelitian yang dilakukan oleh Tangkeallo \& Tangdialla (2021) serta Cahyani, Wiyono, \& Benty (2020) dalam penelitiannya terdapat pengarus positif signifikan pendidikan kewirausahaan terhadap minat wirausahaa, maka dari itu bahwa hipotesis 1 penelitian ini diterima.

b. Pengaruh lingkungan keluarga terhadap minat berwirausaha 


\section{https://journal.univetbantara.ac.id/index.php/jbfe}

Hasil penelitian menunjukkan bahwa lingkungan keluarga tidak berpengaruh terhadap minat berwirausaha Mahasiswa Fakultas Ekonomi Universitas Veteran Bangun Nusantara Sukoharjo. Hal ini ditunjukkan dari hasil uji T atau uji parsial bahwa $\mathrm{T}_{\text {hitung }}<\mathrm{T}_{\text {tabel }}$ yaitu 1,304 $<1,666$. Hasil penelitian ini tidak mendukung penelitian dari Arisanti \& Nafitasari (2020) dan Aini \& Oktafani (2020) yang hasilnya terdapat pengaruh positif signifikan antara lingkungan keluarga dengan minat berwirausaha, maka dari itu bahwa hipotesis 2 dalam penelitian ini ditolak.

c. Pengaruh pendidikan kewirausahaan dan lingkungan keluarga secara simultan terhadap minat berwirausaha

Hasil penelitian menunjukkan bahwa pendidikan kewirausahaan dan lingkungan keluarga berpengaruh simultan terhadap minat berwirausaha. Hal ini ditunjukkan dari hasil uji $\mathrm{F}$, bahwa variabel pendidikan kewirausahaan dan lingkungan keluarga dalam penelitian ini berpengaruh secara simultan terhadap variabel minat berwirausaha Mahasiswa Fakultas Ekonomi Universitas Veteran Bangun Nusantara Sukoharjo. Dengan hasil nilai $F_{\text {hitung }}>F_{\text {tabel }}$ yaitu $6,919>3,12$. Hasil penelitian ini mendukung penelitiannya Wahyuningsih (2020) serta Khoeriyah, Muamar \& Bakhri (2019) yang hasil penelitiannya terdapat pengaruh bersama-sama atau simultan pendidikan kewirausahaan dan lingkungan keluarga terhadap minat berwirausaha, maka dari itu hipotesis 3 dalam penelitian ini diterima.

Tabel 4.13

Kesimpulan Hipotesis

\begin{tabular}{|c|l|l|}
\hline No & \multicolumn{1}{|c|}{ Hipotesis } & \multicolumn{1}{|c|}{ Hasil } \\
\hline 1 & $\begin{array}{l}\text { Pengaruh pendidikan kewirausahaan terhadap } \\
\text { minat berwirausaha }\end{array}$ & Diterima \\
\hline 2 & $\begin{array}{l}\text { Pengaruh lingkungan keluarga terhadap minat } \\
\text { berwirausaha }\end{array}$ & Ditolak \\
\hline 3 & $\begin{array}{l}\text { Pengaruh pendidikan kewirausahaan dan } \\
\text { lingkungan keluarga secara simultan terhadap } \\
\text { minat berwirausaha }\end{array}$ & Diterima \\
\hline
\end{tabular}




\section{KESIMPULAN, KETERBATASAN DAN SARAN}

* Kesimpulan

Penelitian ini dilakukan kepada Mahasiswa Fakultas Ekonomi Universitas Veteran Bangun Nusantara Sukoharjo. Dari hasil analisis data yang telah dilaksanakan dalam penelitian ini, maka dapat diambil kesimpulan sebagai berikut :

1. Pendidikan kewirausahaan berpengaruh positif terhadap minat berwirausaha

Dalam penelitian ini menunjukkan bahwa hipotesis pertama didukung, dengan pendidikan kewirausahaan berpengaruh positif terhadap minat berwirausaha. Hal ini berarti pendidikan kewirausahaan yang diberikan oleh Fakultas Ekonomi Universitas Veteran Bangun Nusantara Sukoharjo kepada mahasiswa dapat mempengaruhi minat berwirausaha mahasiswa.

2. lingkungan keluarga tidak berpengaruh terhadap minat berwirausaha

Dalam penelitian ini menunjukkan bahwa hipotesis kedua ditolak, dengan lingkungan keluarga tidak berpengaruh terhadap minat berwirausaha. Hal ini berarti bahwa lingkungan keluarga tidak berpengaruh terhadap minat berwirausaha mahasiswa Fakultas Ekonomi Universitas Veteran Bangun Nusantara Sukoharjo.

3. Pendidikan kewirausahaan dan lingkungan keluarga berpengaruh secara simultan terhadap minat berwirausaha

Dalam penelitian ini menunjukkan bahwa hipotesis ketiga diterima, dengan hasil pembahasan pendidikan kewirausahaan dan lingkungan keluarga berpengaruh secara simultan terhadap minat berwirausaha. Hal ini berarti bahwa pendidikan kewirausahaan dan lingkungan keluarga berpengaruh terhadap minat berwirausaha Mahasiswa Fakultas Ekonomi Universitas Veteran Bangun Nusantara Sukoharjo.

Keterbatasan Penelitian

Keterbatasan yang ditemui pada waktu penelitian yaitu sebagai berikut:

1. Tempat penelitian yang digunakan dalam penelitian ini hanya berfokus pada satu Fakultas saja yaitu Fakultas Ekonomi Universitas Veteran Bangun Nusantara Sukoharjo. Dengan keterbatasan tersebut maka hasil dari penelitian ini hanya bisa untuk mengukur minat berwirausaha Mahasiswa pada Fakultas Ekonomi, dan belom bisa menjadi acuan untuk mengukur minat berwirausaha pada Fakultas lain di Universitas Veteran Bangun Nusantara Sukoharjo.

2. Dalam pengambilan data, penelitian ini menggunakan kuesioner. Namun, dalam proses penyebaran terdapat keterbatasan untuk mendistribusikan kuesioner secara langsung atau 
offline kepada responden. Hal ini dikarenakan pandemic covid-19, sehingga kuesioner diserahkan kepada responden secara online menggunakan google form.

\section{* Saran}

Saran yang dapat diberikan adalah sebagai berikut :

a. Saran untuk peneliti selanjutnya

1. Terkait adanya keterbatasan tempat yang digunakan dalam penelitian ini, diharapkan penelitian selanjutnya dapat mencangkup lingkup Universitas. Sehingga dapat mengetahui minat berwirausaha mahasiswa dilingkup universitas khususnya pada Universitas Veteran Bangun Nusantara Sukoharjo.

2. Terkait adanya keterbatasan dalam teknik penyebaran kuesioner, diharapkan peneliti selanjutnya mendistribusikan kuesioner secara langsung kepada responden dan menambah wawancara atau pertanyaan terbuka untuk mengetahui respon responden secara langsung dan lengkap dengan mematuhi protocol kesehatan yang berlaku.

b. Saran untuk fakultas

Berdasarkan hasil penelitian yang dilakukan dalam penelitian ini ada faktor yang dapat mempengaruhi minat berwirausaha mahasiswa yaitu pendidikan kewirausahaan dan selain itu lingkungan keluarga tidak berpengaruh terhadap minat berwirausaha.

a. Saran dari peneliti untuk fakultas, diharapkan memberi kepercayaan atau tanggung jawab kepada setiap mahasiswa untuk membangun bisnis dari semester awal hingga akhir dengan didampingi oleh dosen pembimbing yang ahli dibidang kewirausahaan, yang nantinya bisnis yang dibangun bisa di jalankan saat mahasiswa lulus atau selesai setudinya. Hal ini dikarekan bahwa pendidikan kewirausahaan yang meliputi mata kuliah kewirausahaan, praktik kewirausahaan dan mengelola uang berpengaruh terhadap minat berwirausaha.

b. Variabel lingkungan keluarga tidak berpengaruh terhadap minat berwirausaha. Hal ini dikarenakan kurangnya sosialisasi dan pemahaman terhadap masyarakat mengenai pentingnya berwirausaha. Untuk menyikapi ini peneliti memberi saran kepada fakultas untuk memberi kepercayaan atau tanggung jawab kepada setiap mahasiwa untuk memprsentasikan hasil bisnis yang dibangunya dari semester awal kepada masyarakat, agar nantinya masyarakat termotivasi bahwa berwirausaha itu penting untuk menentukan karir dimasa yang akan datang. 


\section{DAFTAR PUSTAKA}

Adi jaya , I. b., \& seminari, n. k. (2016). pengaruh norma subjektif, efeksi diri, dan sikap terhadap intensi berwirausaha siswa smkn di denpasar. E-Jurnal Manajemen Unud, $5(3), 1713-$

1741.

Aini, Q., \& Oktafani, F. (2020). Pengaruh Pengetahuan Kewirausahaan, Motivasi Berwirausaha dan Lingkungan Keluarga Terhadap Minat Berwirausaha Mahasiwa Fakultas Komunikasi dan Bisnis Telkom University. Jurnal Ilmiah Ekonomi dan Bisnis, 17, 151-159.

Anand, F., \& Meftahudin. (2020). Pengaruh Lingkungan Keluarga, Pendidikan Kewirausahaan, Efikasi Diri dan Motivasi Terhadap Minat Berwirausaha Mahasiswa. Jurnal of Economic, Business, and Engineering (JEBE), 2, 88-97.

Arisanti, P., \& Nafitasari, R. R. (2020). Pengaruh Lingkungan Keluarga Terhadap Minat Berwirausaha Mahasiswa Politeknik Cahaya Surya Kediri. Ekuivalensi Jur nal Ekonomi Bisnis, 6, 208-217.

Cahyani, D. P., Wiyono, B. B., \& Benty, D. D. (2020). Pengaruh Pendidikan Kewirausahaan dan Praktik Kerja Lapangan Unit Bisnis Center terhadap Minat Berwirausaha. JAMP: Jurnal Adminitrasi dan Manajemen Pendidikan, 3, 110-117.

Ferdinand, A. (2014). Matode Penelitian Manajemen (5 ed.).

Ghurfiana, E. L. (2018). pengaruh mata kuliah pendidikan kewirausahaan dan lingkungan keluarga terhadap minat berwirausaha mahasiswa ips universitas islam negeri maulana malik ibrahim malang. 1-91. 
Journal of Business Finance and Economic (JBFE)

P-ISSN: 2746-6906

Volume 2, Nomor 2, Desember 2021

E-ISSN: 2746-6914

https://journal.univetbantara.ac.id/index.php/jbfe

Herawati. (2018). pengaruh pendidikan kewirausahaan dan limgkungan keluarga terhadap minat berwirausaha bagi mahasiwa fakultas ekonomi dan bisnis islam uin alaudin makassar. 162.

Hutagalung, B., Dalimunthe, D. M., Pambudi, R., Hutagalung, A. Q., \& Muda, I. (2017). The Effect of Enterpreneurship Education and Family Environment Towards Students' Entrepreneurial Motivation. Internasional Journal of Economic Research, 14, 331-348.

Khotimah, S. (2020). Faktor-Faktor yang Mempengaruhi Minat Wirausaha Siswa Kelas XI Jurusan Jasa Boga SMK Negeri 3 Purwokerto. Jurnal Pendidikan, Hukum, dan Bisnis, 5, $21-27$.

Kurnia , T., Muhlisin, H., \& Munawar, W. (2017). faktor-faktor yang mempengaruhi motivasi mahasiswa menjadi entrepreneur. jurnal syarikah jurnal ekonomi islam, 3(1).

Khoeriyah, Y., Muamar , A., \& Bakhri , S. (2019). Pengaruh Pendidikan Kewirausahaan dan

Keluarga Terhadap Minat Berwirausaha Darut-Tauhid Al-Ishlah Cirebon. 4, 98-111.

Latief, M. J. (2017). Kewirausahaan (kiat sukses menjadi wirausaha). 2.

Lestari, B. R., \& Wijaya, T. (2012). Pengaruh Pendidikan Kewirausahaan terhadap Minat Berwirausaha Mahasiswa di STIE MDP, STMIK MDP, dan STIE MUSI. Jurnal Ilmiah STIE MDP, 1(2), 112-119.

M. Yusuf, \& Sutanti. (2020). Pengaruh Pendidikan Kewirausahaan dan Lingkungan terhadap

Minat Berwirausaha dikalangan Mahasiswa. Jurnal UMJ, 1(2), 77-84.

Munawar, A. (2019). Pengaruh Pendidikan Kewirausahaan Dan Self Efficacy terhadap Minat

Berwirausaha Siswa. Proseding Seminar Nasional Pendidikan Kaluni, 2, 398-406. 
Journal of Business Finance and Economic (JBFE)

P-ISSN: 2746-6906

Volume 2, Nomor 2, Desember 2021

E-ISSN: 2746-6914

https://journal.univetbantara.ac.id/index.php/jbfe

Novitasyari, W., Setiawati, T., \& Rahmawati, Y. (2017). minat berwirausaha mahasiswa program studi pendidikan tata boga universitas pendidikan indonesia. media pendidikan, 6(2), 8193.

Oktarina, H., Agung, E. A., \& Aswad, S. H. (2019). Pengaruh Lingkungan Keluarga Terhadap Minat Berwirausaha Mahasiswa Pendidikan Ekonomi STKIP Pembangunan Indonesia. Stiedewantara, 49-54.

Omardi, O. B., Talkah , A., \& Daroini, A. (2020). Pengaruh Pendidikan Kewirausahaan, Lingkungan Keluarga dan Efikasi Diri Terhadap Intensitas Berwirausaha di STKIP PGRI Tulungagung (Studi Pada Mahasiswa Pendidikan Ekonomi Tahun 2019-2020). Otonomi, 20, 179-190.

Perkasa, D. H., Triansah, F., \& Iskandar, D. A. (2020). Peran Pendidikan Kewirausahaan dan Motivasi Berwirausaha dalam Mempengaruhi Minat Berwirausaha Mahasiswa. neolectura, 2, 106-114.

Sugiyono. (2011). Metode Penelitian Kombinasi (Mexed Methods). 11-136.

Tangkeallo, D. I., \& Tangdialla, R. (2021). Analisis Pendidikan Kewirausahaan dan Penggunaan Media Sosial Terhadap Minat Berwirausaha Mahasiswa Fakultas Ekonomi UKI Toraja. JEKPEND (Jurnal Ekonomi dan Pendidikan), 4, 75-79.

Wahyuningsih , R. (2020). Pengaruh Pendidikan Kewirausahaan dan Lingkungan Keluarga Terhadap Minat Berwirausaha Mahasiswa STKIP PGRI Jombang. Jurnal Kependidikan: Jurnal Hasil Penelitian dan Kajian Kepustakaan di Bidang Pendidikan, Pengajaran dan Pembelajaran, 6, 512-521. 
Journal of Business Finance and Economic (JBFE)

https://journal.univetbantara.ac.id/index.php/jbfe

Widianingrum, E. (2020). Pengaruh Efikasi Diri dan Lingkungan Keluarga Terhadap Minat Wirausaha Siswa SMK di masa Pandemi COVID-19. Jurnal Ekonomi dan Manajemen, 2, $1-9$.

Zulfikar, R., \& Sobandi, A. (2020). Studi Tentang Pengaruh Pendidikan Kewirausahaan terhadap Minat Berwirausaha Mahasiswa Universitas Bangka Belitung. JARTIKA, 3(1), 127-129.

Data jumlah tingkat pengangguran terbuka (TPT) Agustus tahun 2020. https://www.bps.go.id/pressrelease/2020/11/05/1673/agustus-2020--tingkat-pengangguranterbuka--tpt--sebesar-7-07-persen.html (diakses 22 februari 2021) 